Otterbein University

Digital Commons @ Otterbein

Summer 2014

\title{
Temporary Protection, Enduring Contradiction: The Contested and Contradictory Meanings of Temporary Immigration Status
}

Miranda Cady Hallett

Otterbein University

Follow this and additional works at: https://digitalcommons.otterbein.edu/socio_fac

Part of the Anthropology Commons, and the Sociology Commons

\section{Repository Citation}

Hallett, Miranda Cady, "Temporary Protection, Enduring Contradiction: The Contested and Contradictory Meanings of Temporary Immigration Status" (2014). Sociology Faculty Scholarship. 1.

https://digitalcommons.otterbein.edu/socio_fac/1

This Article is brought to you for free and open access by the Sociology at Digital Commons @ Otterbein. It has been accepted for inclusion in Sociology Faculty Scholarship by an authorized administrator of Digital Commons @ Otterbein. For more information, please contact digitalcommons07@otterbein.edu. 


\begin{tabular}{|l|l|}
\hline Journal Code: LSI & Proofreader: Mony \\
\hline Article No: LSI12081 & Delivery date: 29 May 2014 \\
\hline Page Extent: 22 & \\
\hline
\end{tabular}

Law $\mathcal{E}$ Social Inquiry

Volume $\bullet \bullet$, Issue $\bullet \bullet, \bullet \bullet-\bullet \bullet, \bullet \bullet 2014$

\section{Temporary Protection, Enduring Contradiction: The Contested and Contradictory Meanings of Temporary Immigration Status}

Miranda Cady Hallett

In the construction of immigration status categories in law and social practice, the power of the nation-state to define migrants' status is pervasive but far from absolute. In this article, I examine the conditioned legality known as Temporary Protected Status (TPS) in US immigration law through a discussion of legal structures, historical frames, local discourses, and Salvadoran migrants' lived experiences with liminal legality in rural Arkansas in the first decade of the twenty-first century. I argue that migration policy, though fraught with ambiguity and contradiction (see Coutin 2007; Coutin and Yngvesson 2008), functions both to reproduce and to mask the benefits to the nation-state from the ambiguous inclusion and simultaneous exclusion of migrant workers. In spite of the efficacious ways immigration policies discipline and constrain, within these limits migrants, legal practitioners, and others respond as critical agents to the policy structures shaping their lives.

TPS is like a gift from God.

Roy Petty, Immigration Attorney, March 2008

The TPS, the guest worker programs, they are the perfect way to keep people in a second-class status. This may sound harsh, but it's really like a form of slavery.

Ana Hart, Tyson Community Outreach Coordinator, March 2007

\section{INTRODUCTION}

A small but growing number of transnational migrants live and work in the United States under the auspices of temporary visas, which permit work and residency, but fail to provide the opportunity to acquire full citizenship status. Worker visas, such as those distributed under the H2-A program, have grown from less than 10,000 a year in 1992 to

Miranda Cady Hallett is Assistant Professor of Cultural Anthropology at the Department of Sociology and Anthropology at Otterbein University and can be contacted at mhallett@otterbein.edu. The fieldwork conducted for this article, a prior version of which appears as a chapter in the author's 2009 doctoral dissertation titled Disappeared Subjects: Migration, Legality and the Neoliberal State, was partially funded by a 2006-2007 Sage Fellowship through the Department of Anthropology at Cornell University and approved by Cornell's Institutional Review Board. The author thanks Jamie Longazel and Maartje van der Woude as well as the anonymous reviewers for feedback on this work. Thanks and acknowledgment is also due to the participants in the research interviews, named and unnamed, whose words are quoted herein. They were generous with their time and with their thoughtful reflections on TPS. 


\section{LAW \& SOCIAL INQUIRY}

over 50,000 in fiscal year 2011 (Bruno 2012, 5). Relatively novel status possibilities such as the TPS program likewise define the legality of more than 300,000 foreign nationals hailing from seven different countries of origin; by far the largest number are migrants originating from El Salvador (Wasem and Ester 2011, 4). ${ }^{1}$ As comprehensive immigration reform proposals are debated in the early twenty-first century, the possibility of greater numbers of guest workers is continually on the table. In this article, I explore the political, economic, and sociocultural meanings of the TPS program, as the alleged benefit shapes the lives and experiences of Salvadorans living in rural Arkansas. Whether TPS is a benefit is a matter of debate on the ground, as the divergent statements with which I open this article suggest. While the status usually shields recipients from deportation $^{2}$ and usually provides them with a legitimate work permit card, ${ }^{3}$ it also subjects migrants to what Cecilia Menjívar (2006) has called liminal legality. TPS makes migrants more susceptible to visibility and surveillance, constrains their mobility, disciplines their working lives, and subjects them to an indefinite state of temporariness. ${ }^{4}$

To approach the complex symbolic and social implications of TPS, I use mixed methods of discourse and legal statute analysis juxtaposed with ethnographic research and unstructured interviews with Salvadoran migrants and legal practitioners in Arkansas. Relying on these data, I argue that three basic contradictions shape the TPS program. The first involves ambiguity in the framing of the history and purpose of the program. Although the initial TPS program in 1991 came about as the result of mobilization and activism on the part of Salvadorans and entailed the states' partial recognition of the disastrous results of US foreign policy in El Salvador, the twentyfirst-century manifestation of the benefit has a distinct framing as a humanitarian aid project. The second concern is the way TPS simultaneously fosters inclusion and exclusion. While providing migrants with legal papers in the form of a valid work permit, migrants with TPS are defined as nonimmigrants and their files and records can be used to deport them upon termination of the program. Finally, I explore the ways the program overall enables the state to reconcile contradictory tensions in the era of neoliberal restructuring. Simultaneously responding to labor market demands through the partial inclusion of temporary workers and responding to nativist anxieties over political and cultural sovereignty through their partial exclusion, the TPS program, like other ambiguous legal statuses, helps the nation-state mediate these contradictions.

1. TPS, as discussed in greater detail later, is specifically linked historically to the legal and moral claims exerted on the US government by Salvadoran activists in the 1980s who asserted that their displacement due to El Salvador's civil war was the responsibility of US military aid to government death squads. Although the program is currently framed as a humanitarian benefit extended to its recipients, nonetheless the eligibility of various countries' nationals for refuge under the program reflects historical links to US foreign policy interventions: El Salvador, Haiti, Honduras, Nicaragua, Somalia, the Sudan, and Syria.

2. In their research on deportees in El Salvador, two colleagues found that at least one young man with TPS was rounded up in a workplace raid and deported to El Salvador. Throughout his detainment, he insisted that he had a work permit and refused to sign the paper giving his permission for voluntary removal. According to his testimony, five officers restrained him physically while another applied electric shock to his hands so he would unclench his fists. This officer inked his fingerprints and pressed them down on the paper (María Candelaria Navas and Elsa Ramos, personal communication, May 30, 2008).

3. Although often the renewed card will arrive long after the expiration date of the previous one.

4. While other scholars have coined terms to refer to the status itself-such as twilight status (Motomura 2008) or legal limbo (Mountz et al. 2002) - this concept refers specifically to the condition of social and spatial constraint experienced by migrants who live under the status. 
Throughout the article, I explore how migrants respond as critical agents to the contradictions and ambiguities described above. They negotiate the cultural and legal minefield of liminal status, both its pragmatics and its semiotics. In migrants' own narratives, the program is often critiqued for its political and symbolic ramifications as well as the partialities of its benefits. Migrants negotiate both the symbolic meanings (gift, debt, right, privilege, the morality of eligibility) and the practical functioning (biometrics, fees, efficiency of processing, mobility) of the TPS status in their readings of the policy and its flaws. While some legal practitioners view the status as a blessing or a gift - and some migrants rhetorically push the boundaries of the status to broaden their claims to belonging-as a whole, migrants are critical of its exclusionary elements and of the ways TPS subjects their lives to discipline and constraint.

In this analysis, I take discourses emerging from a particular time and placenorthwestern Arkansas in the mid-2000s_as a point of entry for a broader exploration of the possible ideological, structural, and social implications of temporary legalities in immigration policy. However, the significance of this analysis does not end with the limits of temporary legal status programs, which account for a minimal number of migrants in comparison to legal permanent residency and unauthorized status. Elsewhere, scholars have argued for the significance of many other forms of liminal legality and qualified citizenship (see Ong 1999; Calavita 2005; Sadowski-Smith 2009) and demonstrated that such graduated forms of alienation and citizenship resonate in the present neoliberal era (Motomura 2008; Kretsedemas 2009; Cacho 2012). Here, I argue that the ambiguities highlighted through a focus on liminal legality reveal dynamics and contradictions that pervade citizenship law-fundamental tensions in the way the state treats legal persons - which remain occluded in other legal forms.

In arguing for these broader implications, I also build on recent scholarship theorizing contemporary immigration law as a system of legal violence (Menjívar and Ábrego 2012), research on the political economy of migration policy (Massey, Durand, and Malone 2002; Mize and Swords 2010), and the insights of legal anthropologist Susan Coutin regarding the ambiguity of immigration law and status as a contested social process $(1998,2000,2007,2011)$. Contributing to the work of these theorists, the analysis presented here highlights the critical voices of migrants as they contest and interpret TPS, concluding that the nexus of migrant agency and status ambiguity reveals dynamics beyond the particular program and migrant community involved. Migrant voices are presented in juxtaposition to an analysis of the nation-state's framing ideology in order both to point out the limits of such hegemonic constructions of legal policy regimes and to highlight how law's threshold is "both bounded and limitless" (Coutin and Yngvesson 2008, 2).

\section{BACKGROUND: LITERATURE, SETTING, AND METHODS}

\section{Theorizing the Technologies of Immigrant Exclusion}

Historically, immigration and naturalization laws and exclusionary policies have been central to the construction of racial categories in the United States and the policing of boundaries of national belonging, as well as the construction of racialized 


\section{LAW \& SOCIAL INQUIRY}

labor systems (Haney López 1996; Le Espiritu 2000; Ngai 2005; Mize and Swords 2010). This continues to be the case in the contemporary moment. My approach here is simultaneously attentive to the fluidity and flexibility of law (Coutin 2000, 2007, 2011) and the way law as a technology of governance and "enframing" forecloses certain ways of knowing while enshrining a particular narrative as truth and particular subjectivities as valid and nameable (Coutin and Yngvesson 2008, 2-3). This foreclosure of multiple and ambiguous semiotic meanings reinforces the function of immigration in terms of political economy: law constructs racialized legal-social hierarchies that reproduce and fulfill the needs of segmented labor markets (Le Espiritu 2000; Massey, Durand, and Malone 2002).

As numerous other scholars have documented, legality is not a choice made by migrants, nor a quality of their personhood; rather, it is a set of categories, disciplines, and practices produced by laws and legal institutions and imposed on migrants and migrant bodies (Calavita 1998; De Genova 2005; Ngai 2005). What Cecilia Menjívar (2006) calls liminal legality helps construct racialized and stratified social positions that articulate with local and national communities of belonging. The state's production of categories of migrants, of which the TPS is only one example, constitutes some groups of migrants as a laboring lower class within a hierarchy of citizenship, utilizing state policy to articulate migrants within social and economic regimes. ${ }^{5}$

Although previous immigration law regimes and state responses to transnational migration have shifted over time, they nonetheless consistently structure and enable labor exploitation of Latin American and other migrants-especially through the construction of categories of indefinitely liminal legality (Mize and Swords 2010; Paret forthcoming). In this vein, TPS helps to bind and mediate the gaps and confluences between labor market demands, xenophobia and social exclusion, and the need for a public enactment of state sovereignty through surveillance, documentation, and the apparent tidiness of statutory distinctions. Within migrants' lives, the inherent contradictions within these policies and status categories are deeply felt and highly visible, causing a heightened legal consciousness with diverse critical and ideological responses.

The fundamental importance of this structural dynamic has been well-documented by other scholars; ${ }^{6}$ however, my analysis here also emphasizes the important role of discourse in the cultural construction of meanings and ideologies that both reproduce and contest the order of the neoliberal nation-state, an order that mediates challenges and contradictions based in global fluidity and popular perceptions of insecurity. By highlighting throughout the voices and agency of Salvadoran migrants and legal practitioners, even in the constrained political context of rural Arkansas, this material demonstrates how everyday agents reframe and contest the meanings of the TPS program. Their responses highlight the already-present gaps and contradictions in

5. It is worth noting that Sadowski-Smith (2009) suggests that, symbolically, scholarship on the subordination of migrants risks reifying these migrants' identities as centered on hard work-with problematic racializing and essentializing implications.

6. Some (Massey, Durand, and Malone 2002; Massey 2008a) describe this as a relatively stable system of building an underclass-not denying the presence of exploitative dynamics, but subsuming them in a functionalist reading - while others (Ngai 2004; Mize and Swords 2010) foreground the inhumane and 5 manipulative aspects of guest worker programs and other legal exclusions, aligning their intellectual work with the efforts of activists and advocates for a more just system. 
temporariness as a technology of law (Coutin and Yngvesson 2008, 2). Overall, the case of TPS demonstrates another way that in the contemporary moment "exceptions" to law-such as the concept of temporariness itself-are no longer used simply to suspend law, but are employed as structured lacunae within the law itself (Agamben 2005; Kretsedemas 2009, 61). In other words, the apparent simplicity of the statutes in the Federal Register, laid out in black and white, belie the way in which the very ambiguity of the program serves as a release valve for the irresolvable contradictions inherent in immigration policy: contradictions between state authority and global flows as well as blurred boundaries between conditions of sociolegal inclusion and sociolegal exclusion.

Though unauthorized migrants are often referred to as undocumented, migration scholars have worked to reframe the social and cultural dimension of this legal condition as deportability (De Genova 2002) rather than lack of documentation. In truth, most migrants' lives involve significant forms of documentation, or the construction of an official papereality (Dery 1998) establishing the identity of a person and tracking their activities and locations through institutional texts. This set of documents constructing a bureaucratic reality for migrants' identities, proving and producing their presence in the eyes of state officials, can range from immigration paperwork to tax records, student records, or police reports. The papereality of migrants accumulates and forms a set of resources or liabilities that may be invoked when facing the immigration court system.

Despite the usual binary analysis and comparison of so-called undocumented migrants with legally authorized immigrants, there are also numerous other legal statuses that do not fit neatly in either category. The arcane and ambiguous eligibility requirements for each particular legal program, with their mix of technical and moral claims required, make immigration policy a labyrinthine mystery to most of those who are impacted by it. Hiroshi Motomura $(2008,2048)$ calls these liminal status categories "twilight statuses," arguing that they help construct implicitly racialized hierarchies of citizenship, framing differential access to rights (see also Massey and Bartley 2005; Menjívar 2006).

The technocratic opacity of these twilight statuses, as well as the murky ambiguity of the immigration law system as a whole, is navigated on behalf of their clients by the lawyers, notaries, and others that practice law (Lakhani 2014). At times, practitioners invoke the sleight of hand required in navigating law as a part of their professional magic while attempting to negotiate this ambiguous field-Sarah Lakhani mentions one who refers explicitly to the required documentation as the papél mágico or magic paper. Migrants unsure of their status and potential status in relation to the law seek out the magical promise of papers, or legal identity documents, by appealing to these practitioners, seeking certainty through their claims, and enacting the requisite bureaucratic rituals of paperwork. Nonetheless, even those who acquire papeles in the form of a temporary work permit or even a green card often find that the elevation of status acquired by means of such artifacts is dubious at best. Some are able to acquire temporary work permits, only to find that these tie them to particular employers, have an expiration date upon which they may be deported, or may require biometric surveillance by the state.

In my own fieldwork, both experts in immigration law and clients seeking immigration policy status adjustments, frequently referred to as "benefits," often describe the legal code, as well as the bureaucratic system implementing immigration law, as an 


\section{LAW \& SOCIAL INQUIRY}

over-rationalized bureaucratic iron cage. They use such terms as "confusing," "arcane," and "labyrinthine," as well as asserting that the system is "outdated" or "archaic." The latter claim regarding the temporal datedness of the system ironically fails to recognize how the dysfunctions of the shifting system are in reality quite contemporary, flexible, and responsive, forming the cutting edge of legal violence for those subjected to these forms of liminal legality and graduated sovereignty (see Ong 2006; Kretsedemas 2009). The complexity of the system and the difficulty for many of finding a route to permanent residency are undeniable, contributing to a vibrant market in false identity documents or papeles chuecos (dirty papers) and subjecting residents within the national territory to varying regimes of management and discipline.

\section{Liminally Legal in Arkansas: Setting and Methods}

Danville, Arkansas, the primary site of my 2005-2008 ethnographic fieldwork, is a quiet and sleepy town with a population of around 2,400 residents located approximately halfway between Little Rock and Fort Smith in central western Arkansas. About half the households in town are headed by Latin American migrants who have relocated to the region within the past ten to twenty years (see Table 1 for recent US Census data). Yell County, of which Danville is the county seat, is located in a rural area in the Ouachita Mountains. It is a dry county, where the sale of alcohol is legally prohibited, and conservative evangelical churches as well as the leadership of the local poultry industry dominate local political life. During the time of my research, the town of Danville was home to two large poultry processing plants employing around 1,500 people in the small town.

While the chicken processing industry is especially dense in Yell County, the economic landscape of the entire northwestern half of Arkansas is dominated by poultry agribusiness. Home to the corporate headquarters of Tyson Foods, the largest meat

\section{TABLE 1.}

Growth of the Latino population in Yell County, with Comparative Figures from the Town of Danville, and the State of Arkansas

\begin{tabular}{lccccc}
\hline & $\begin{array}{c}\text { Total } \\
\text { Population } \\
\text { Yell County }\end{array}$ & $\begin{array}{c}\text { Total } \\
\text { Population } \\
2000\end{array}$ & $\begin{array}{c}\text { Growth } \\
\text { Rate } \\
1990-2000\end{array}$ & $\begin{array}{c}\text { Total } \\
\text { Population } \\
2010\end{array}$ & $\begin{array}{c}\text { Growth } \\
\text { Rate } \\
2000-2010\end{array}$ \\
\hline Total population & 1990 & 21,139 & $+19 \%$ & 22,185 & $+5 \%$ \\
Hispanic/Latino & 177 & 2,691 & $+1420 \%$ & 4,230 & $+57 \%$ \\
Salvadoran & 11 & 348 & $+3064 \%$ & $n / \mathrm{a}$ & $n / a$ \\
Foreign born & $\mathrm{n} / \mathrm{a}$ & 2,147 & $n / a$ & 2,728 & $+27 \%$ \\
Danville total & 1,588 & 2,392 & $+51 \%$ & 2,409 & $+<1 \%$ \\
$\quad$ Hispanic/Latino & 34 & 1,040 & $+2,959 \%$ & 1,268 & $+22 \%$ \\
Arkansas total & $2,350,725$ & $2,673,400$ & $+14 \%$ & $2,915,918$ & $+9 \%$ \\
$\quad$ Hispanic/Latino & 19,876 & 86,866 & $+337 \%$ & 186,050 & $+114 \%$ \\
Salvadoran & $\mathrm{n} / \mathrm{a}$ & 3,471 & $n / a$ & $n / a$ & $n / a$ \\
& & & & & \\
\hline
\end{tabular}

Source: Data drawn from the US Census (www.usfactfinder.gov). 
producer in the world, a great number of Arkansans are caught up in the vertical production chains by raising, catching, slaughtering, disassembling, or processing the birds. Since John Tyson began the business in the 1930s, it has grown to be the nation's broiler capital, overtaking and surpassing earlier geographic centers like the Delmarva Peninsula and parts of North Carolina (Striffler 2005).

Concerning not only the conditions of legality experienced by migrants, but also the intersection of these conditions with the local political economy and labor management regimes, my 2006-2008 fieldwork research was multisited and my inquiry covered diverse themes. The methods centered on a practice of participant observation in a wide range of settings: churches, homes, and restaurants where Salvadoran migrants meet to socialize, and special events such as quinceañeras, birthday parties, and Palm Sunday processions. I also observed workers' rights educational meetings, labor complaint interviews, day-to-day interactions in the Northwest Arkansas Workers' Rights Center, numerous public or corporate events that dealt with immigration, such as Tyson diversity programs, university forums, and public town hall meetings. In addition to this, I conducted extensive open-ended interviews with more than forty individuals in Arkansas and many others in El Salvador as I accompanied one migrant back home and met with family members of several others who could not leave Arkansas. While many of the statements quoted herein come from the open-ended interviews, a great number also come from informal conversations and the entire analysis is informed by my own experiences as a participant observer. ${ }^{\text {? }}$

Throughout the research, my areas of analytical focus included legal status issues, labor disciplining and labor rights claims, corporate politics in relation to migration flows, the formation of local, national, and transnational identities, sending and receiving states' articulation with migrant communities, and transforming racial formations in Arkansas, particularly in rural areas of high migration. The open-ended, subjective, and free-form nature of the research methods enabled a complex and holistic approach to understanding the mutual constitution of legal status, labor production regimes, transnational and national identities, and racial formations. While the unique localities of my data collection shape the results, nonetheless this approach led to insights that can be generative for theorizing citizenship and law more broadly, as well as comprehending the experiences of migrants in new immigrant destinations (Massey 2008b; Marrow 2011), especially in the South.

In new sites of Latino settlement, such as Arkansas and other southern and midwestern towns, many locally-born residents conceptually collapse all Latinos into the category "illegal Mexicans" regardless of their national origin or legal status. Although an estimated 51 percent of the foreign born in Arkansas were undocumented around the time of my fieldwork (Capps et al. 2007), public and media discourses in Arkansas regarding immigration generally glossed over internal differences of status or origin and classed the issue of immigration as the "problem" of "illegals." Under these conditions, legality not only references formal status, but also indicates a site of social production where perceptions of law and legal categories structure social conditions. These conditions of socially constructed illegality are partially built through racialized

7. In conjunction with my participant observation, I also worked as an educator and advocate for the Northwest Arkansas Workers Justice Center from 2006-2007. 


\section{LAW \& SOCIAL INQUIRY}

TABLE 2.

Labor Force Data for Foreign-Born and Latino Populations in Arkansas, with Growth in Numbers of Workers from 1990-2010

\begin{tabular}{lcccccc}
\hline Arkaansas & 1990 & 2010 & $\begin{array}{c}\text { Percent of } \\
\text { Labor Force } \\
2010\end{array}$ & $\begin{array}{c}\text { Percent of } \\
\text { Workers in } \\
\text { Manufacturing }\end{array}$ & $\begin{array}{c}\text { Percent of } \\
\text { Workers in } \\
\text { Construction }\end{array}$ & $\begin{array}{c}\text { Percent of } \\
\text { Workers in } \\
\text { Agriculture }\end{array}$ \\
\hline $\begin{array}{c}\text { Total number of } \\
\text { workers }\end{array}$ & 944,800 & $1,169,400$ & 100 & N/A & N/A & N/A \\
$\begin{array}{l}\text { Foreign-born } \\
\text { workers }\end{array}$ & 12,700 & 77,100 & 6.6 & 12.8 & 15.9 & 9.2 \\
$\begin{array}{l}\text { Latino workers } \\
\text { C,500 }\end{array}$ & 72,500 & 6.2 & 9.5 & 15.1 & 6.8 \\
\hline
\end{tabular}

Source: Compiled using data from Capps et al. (2013).

and nationalist perceptions of Otherness and illegitimate presence. ${ }^{8}$ These legal categories are linked to a social and economic structure that implies high labor participation rates for transnational migrants in Arkansas, as well as segregating recent migrants in relatively low-wage and high-risk industries such as poultry processing, agriculture, and construction (see Table 2).

At the same time, migrants themselves are engaged in a process of constructing, negotiating, and claiming complex configurations of identity and connection to particular places-a process that is fraught with the potential of deportation and displacement. The seemingly disparate areas of inquiry in my analysis are intertwined, on the ground, in a relatively coherent and highly racialized political economic system of inequality - a system that depends as much on its ideological fault lines and lacunae as on its structural base in legal codes and the mode of production.

\section{ANALYSIS AND DISCUSSION}

\section{Defined Deportability: The Contradictory Structure of TPS}

If persons living in the United States are under deportation orders, they can apply for a cancellation of removal based on meeting certain requirements for eligibility, including good character and length of continuous stay in the United States. TPS can be understood as a kind of collective yet temporary cancellation of removal. The granting of TPS hinges on the documentation of conditions of instability in the home country. Unlike refugee status, which hinges on individuals' evidence that they personally are at risk should they return to their countries, TPS is a blanket form of deporta-

8. One of the state-level political representatives stated privately that "the problem" was "Hispanics," rather than "illegal immigration." His sentiments were echoed by several other whites in informal conversation whose opposition to migration was based around a sense that "they"-meaning people of Mexican or Central American origin — "have no business being here." This representative's private comment followed immediately on the heels of a public panel in which he framed "the problem" in terms of migration and the rule of law. 
tion relief applying to all nationals of a particular country that is currently experiencing "extreme poverty, deprivation, violence, and the dislocation brought on by famines or natural disasters" (Wasem and Ester 2011, 1).

Under the status, migrants are under deportation proceedings but cannot currently be deported. They are technically defined as nonimmigrants to the United States: "an alien is considered as being in, and maintaining, lawful status as a non-immigrant during the period in which the alien is registered under TPS" (Immigration Act 1990, $\S 1254 \mathrm{a}(\mathrm{f})(1))$. The legal statement of permission that allows the migrant worker to be in the United States (and provides him or her with identification in the form of a work permit) also classifies this worker as a nonimmigrant and provides no path to residency or citizenship. More than legally scaffolding the social inclusion of such migrants where they are living, it simply temporarily censures their removal. This status has the "discursive utility of making immigrants appear to be temporary" (Bailey et al. 2002, 127) although in practice many have been resident in the United States for many years, or even several decades. This is the structured lacuna of liminal legality: while in practice the condition can be indefinite-a permanent part of one's sociolegal existence-it is explicitly framed as temporary.

Discourse about TPS, from the level of the statute down to the speech of legal experts, links the program to humanitarian commitments on the part of the United States as an exemplary nation-state. Frank Head, the director of Catholic Charities Immigration Services in Springdale, Arkansas, describes the status this way:

There is a status in immigration called TPS or Temporary Protected Status. First of all in immigration, we divide everything between immigrants and non-immigrants. There are ways to be in the US legally with either one of those categories. An example of a non-immigrant is a tourist. It means you are here legally for a specified amount of time but [you] are not an immigrant. There's an alphabet soup of visas that allow you to be here as a non-immigrant: A, B, C, D, J, M, N, V, all the way to Z. ... One of these is a TPS. This is granted to countries that have suffered a natural disaster-[a] tsunami, an earthquake, a tornado, a hurricane, or some sort of man-made disaster be it war or some facsimile thereof. We allow people who are here undocumented, who come from a country where the conditions are such that to send them back would be inhumane, that Congress decrees these people are allowed to stay for a specified amount of time. While Catholic Charities applauds that the government does this and it's a very important way of not forcing people back into intolerable situations, in practice it's an awkward system because it's always for a very short amount of time, in cases one-year breaks or two years. . . . In terms of El Salvador that [TPS recipients] is by far the majority of the Salvadorans that are undocumented. (Frank Head, personal communication, April 14, 2008, emphasis added)

As Mr. Head's comment suggests, the status of temporary worker is not necessarily understood in contrast with the undocumented condition, socially read as illegality, and in fact he himself frames the status simultaneously as a humanitarian program and as a subset of illegality - in other words, a type of liminal, undocumented status. Section 1254a(f)(1) of the 1990 Immigration Act states "the alien shall not be considered to be permanently residing in the United States under color of law" (emphasis added). TPS is a quasi-documented state (Miyares et al. 2003) that allows Salvadorans to remain in the United States, purportedly due to the ongoing situation of insecurity in El Salvador. 


\section{LAW \& SOCIAL INQUIRY}

The statutes describing the TPS benefit also provide for the continuous biometric surveillance of recipients as well as their eventual deportation when the program comes to an end. Section $1254 \mathrm{a}(\mathrm{e})$ of the TPS statutes states that "the period of such status shall not be counted as a period of physical presence in the United States for purposes of section $1229 \mathrm{~b}$ (a) of this title," indicating that the time that the migrant spends in the United States does not count as residency applying toward eligibility for cancellation of removal. Cancellation of removal is available to undocumented migrants who can prove at their deportation hearing that they have maintained at least ten years continuous residency in the country. This means that a migrant detained under deportation proceedings after ten years of working without any legal documents would have more legal remedies available to him or her, all else equal, than another migrant who had been working for ten years with a TPS work permit.

The TPS recognizes the legal presence and legitimacy of recipients as workers, but officially effaces other aspects of their personhood. One of the requirements of the status is that recipients must "maintain continuous physical presence in the United States" (Federal Register 2006, vol. 71, no. 115, 34639). The statutes require migrants to ask permission from the attorney general if they wish to travel out of country. They may ironically be less mobile than their friends and colleagues with no papers; because they are registered with the Department of Homeland Security, they fear traveling in violation of their work visa and thus potentially losing the card that permits them to work legally. As one informant said to me:

I can't go back. That is, I am welcome to go back, I just have no assurance that they will let me back in the country; it would be at the discretion of the person at the point of entry. I haven't seen my parents since I came here to study journalism in 2000. When the TPS came out I was able to stay and find a job, but now I can't go back to visit. ("Mario," personal communication, February 2007)

TPS recipients are prevented from fully settling in the United States by the alwaysimminent termination of their work permits, yet prevented from returning to El Salvador by the restrictions on those permits-although, perversely, the entire length of their immobilization in the country is not legally recognized as a time of residency. In many cases, the awkward and unworkable system of renewal even fails to provide migrants with the elusive papeles, the physical documentation that verifies their legitimacy as workers and residents:

The only benefit you get from this really is a work permit. A work permit is different from a green card. A green card specifies permanent residency, you can be here forever till you die: you never have to do anything except renew that card. A work permit is something that says you're here for a certain amount of time, usually one year or two, and try again later, re-apply when this runs out. The catch is that the machinery for approving the reapplications is so overburdened that they are frequently_or almost always—stuck in between where the card has run out but their renewal hasn't been approved yet, caught in this limbo where nobody can prove that they are legally or not legally here, well technically there are with immigration because it's pending, but they have no permit to work. (Frank Head, personal communication, April 14, 2008) 
In some cases, migrants with perfectly valid working papers are displaced from their jobs due to a backlog in processing. If they can afford to retain an attorney, a letter from an immigration lawyer explaining the situation and providing copies of the renewal receipts may save them from dismissal, but in other cases, and especially in the past five years as employers have become increasingly fearful of running afoul of Immigration and Customs Enforcement, TPS holders are fired while their unauthorized coworkers may maintain their jobs. Human resources offices are happy to accept any document that appears on its face to be genuine, which is the requirement that legally applies to employers. False or stolen documents generally have no expiration date, while the work permit card carried by Salvadorans with TPS — copied by employers for their I-9 filescontains the date of expiration of the worker's legitimate presence on its face, opening employers who continue to employ them to liability.

Nonetheless, TPS is for many an appreciated status_or a coveted one, depending on whether or not they are eligible. It provides a real legal harbor from some of the anxieties of deportability. It allows for legitimate work, as one informant said:

Right up until now I don't regret [coming to the United States]. I had TPS back in the 90s and until now. With that paper, you can work wherever just like you were legal. ("Graciela," personal communication, July 21, 2007)

As this informant indicates, the possession of TPS allows some migrants to feel and proceed "just like" they were legal. Many Salvadorans interpret and frame TPS as a form of legalization, even though they still lack residency. As Susan Coutin notes:

The fact that immigrants often refer to work permits simply as permisos (permits) rather than permisos de trabajo (work permits) creates ambiguity regarding what the permit is for and suggests that permisos entitle their holders not only to work but to remain in the United States. $(2000,60)$

While the director of Catholic Charities Immigration Services called TPS a form of undocumented status, another lawyer sees it as a type of legalization:

El Salvador, Honduras, and Nicaragua are lucky their nationals have TPS at the moment. If they didn't, yes a lot more of them would be being deported at the moment. Many whose asylum claims, pending after 10 years or so, are now being denied have the opportunity to change their status to TPS. That saves them from being deported. Yes, it is a political tool as the U.S. never has really acknowledged these people as the legitimate refugees that they were when fleeing from the Civil Wars. TPS is temporary, but it is a legal status. I'm sure they would rather be legal than illegal. (Mariana Collins Romero, personal communication, July 2, 2007)

This ambiguity regarding the legal status offered by TPS is only a manifestation of the perplexing nature of legality in the practice of US immigration and citizenship law. As Coutin explains in Nations of Emigrants:

In drawing attention to gaps between immigration as a conceptual system and as a social reality, I do not mean to suggest that if we revise our immigration categories 


\section{LAW \& SOCIAL INQUIRY}

or make some policy adjustments, then these gaps would be closed. Rather, I argue that the immigration system creates the very disjunctures that seem to undermine it and that, moreover, these disjunctures can be key to the immigration system's coherence. $(2007,5)$

Far from being sui generis within the structuring and practice of immigration law, therefore, the statutory discourse and legal structures of TPS highlight the crucial lacuna at the heart of the structure-the exception foundational to the enactment and functioning of this particular law. It highlights the dialectic between absolutist notions of legality and the subtle constructions of validity and worth entailed by law as a social process, revealing the mutability of law and the disjunctive entanglement of legal structures with historical and social realities.

\section{Salvadoran Agency Recast as US Altruism: The Hidden History of TPS}

The role of Salvadorans' agency and the multifaceted meaning of TPS is rooted in the program's contested historical origins: originally, the legal establishment of TPS, followed by the construction of another nonimmigrant status called Deferred Enforced Departure, was a hard-won victory for Salvadoran diplomats and representatives of the states' interests, alongside the work of migrant activist networks and their allies in the United States (Coutin 1998, 2000, 2007). The original framing of TPS in 1991 hinged on a recognition of the difficulties of returning to Central America due to the turmoil and insecurity of civil war, thus serving as a kind of proxy for the refugee status the state refused to grant Salvadorans and Guatemalans. ${ }^{9}$ TPS was a legal compromise intended to mitigate the controversial political disaster of US military intervention in Central America and respond to political pressures from both Salvadoran diplomacy and internal dissidence. TPS status in the early 1990s was only an eighteen-month program, though beneficiaries became eligible to apply for DED, Deferred Enforced Departure, when the program ended-another program that emerged specifically to address the scandal of displaced Central Americans (Coutin 2007). The 1997 Nicaraguan Adjustment and Central American Relief Act eventually provided various pathways to legal permanent residency and a possibility of citizenship for many of the Salvadorans who had utilized TPS initially (Coutin 1998, 2007).

In many ways, TPS status was a political compromise responding to the tension between the needs of refugees from Central America and the US government's unwillingness to admit the failures and abuses of its own foreign policy through the granting of asylum, mediated by the increasing public scandal of those foreign policy choices. By recognizing Guatemalans and Salvadorans as legitimate refugees under existing laws, the state would have thrown into question the legitimacy of its formative financial

9. The US granting of refugee status to Central Americans in the 1980s was a highly political matter. Nicaraguans were generally accepted as refugees due to their claims to repression by a socialist government, while Salvadorans and Guatemalans, fleeing from state violence by regimes supported by the United States, were denied their applications for refugee status (González 2000, 131). As Hamilton and Stoltz Chinchilla state, "as immigrants from 'friendly' countries fighting 'communist subversion,' Salvadorans and Guatemalans could not be welcomed as refugees or entitled to asylum" $(2001,53)$. 
support for the repressive Salvadoran state during the war (Mahler 1995, 30; González 2000, 131). Investigations by the UN Truth Commission after the Chapultepec Peace Accords of 1992 found that the Salvadoran state and affiliated death squads, supported by US military aid, were responsible for over 80 percent of the human rights abuses documented during the twelve-year conflict.

Salvadoran migrants' struggles to be recognized as refugees were often not only motivated by their desire to legalize, but also by the wish to raise these kinds of questions about US foreign policy in Central America. However, with the passage of time, these status benefits have been increasingly depoliticized and their origins in US imperialism occluded. US foreign policy in El Salvador, at least tangentially related to the TPS rationale in 1991, is delinked from the contemporary frame of "natural disaster relief." While the historical context remains important in the memory of many Salvadorans, officially TPS is represented as a humanitarian gesture on the part of the US government.

In January and February 2001, two major earthquakes ravaged central El Salvador. Mudslides buried vast suburban areas of the capital and during the months of tremors following, many people slept outside their homes in spite of the ever-present threat of gang violence. In the aftermath of this natural disaster, both activists and Salvadoran politicians wasted no time in seeking a special recognition for Salvadoran migrants working in the United States under the TPS program. The Salvadoran government submitted a formal request to be considered for TPS on January 17, four days after the first earthquake. On March 19 of the same year, the Attorney General gave notice in the US Federal Register that Salvadorans in the United States would again be eligible for this status, this time due to the depoliticized or allegedly natural disaster of the earthquakes rather than the overtly political disaster of civil war.

Within Salvadoran political contexts, government officials who pressed for the reinstatement of TPS presented it as a diplomatic victory. However, these victories can be a double-edged sword within a global context where the geographies of disaster and aid often reproduce splits of privilege and subalternity, casting the countries of the global North as saving the countries of the global South. When disaster is naturalized in certain geographic spaces, the peoples associated with those national or regional zones can also be stigmatized as perpetual victims, not as potential or actual citizens. ${ }^{10}$

Postcolonial theorists have argued that mechanisms of aid and asylum that are deployed by states serve the interests of the donor state first and foremost. In The Postcolonial Politics of Development, Ilan Kapoor (2008) argues that although aid is performed by powerful nations as a kind of benevolent gift, it is really a form of grift. The gift of aid, whether charity, development, or the safe harbor offered by a status like TPS, is tainted by the self-interest of the giver. Rather than reducing inequalities, Kapoor argues, these relationships reinforce hierarchies between haves and have-nots

10. As the resistance of Katrina victims to being characterized as refugees makes evident, there is a symbolic opposition within popular discourse between those who are citizens, who are entitled to the state's protection along with various benefits and privileges, and humanitarian recipients of aid or asylum, who are defined symbolically as dependent victims whose support is contingent on the benevolence of the state. While this is not always in fit with the formality of legal statutes, this social construction circulates and exerts a powerful hold on the imaginary of national belonging. 


\section{LAW \& SOCIAL INQUIRY}

and produce a sense of obligation on the part of recipients without substantively improving their situation of economic need. Aid as grift allows wealthier nations to reinforce their sense of superiority by performing rituals of generosity and wealth, while increasing their political power through the attachment of conditions to aidoften neoliberal economic policy requirements that will benefit the core nation in the end.

The enactment of benevolence through the gift also ritually fixes and defines a specific historical relation between donor and recipient. TPS served as a kind of proxy for asylee status. But while asylum statutes appeal to international codes emphasizing the right of the refugee and asylee to safe harbor, and the obligation of the state to provide it, the benefit of TPS is represented as a benevolent gift rather than an obligation. Although individual asylees must prove they have special reason to fear, while TPS applies in blanket fashion to all nationals of a particular country-another example of the ironies and ambiguities of these status systems-nonetheless asylum is rhetorically a rights-based claim while TPS is symbolically a humanitarian gesture granted. The notion of gifts given rather than rights protected ratifies a certain historical relationship. The gift is freely given, but requires reciprocity and gratitude on the part of the recipient, while the fulfillment of a right implies that the motivating factor is a foundational obligation on the part of the state.

In the case of asylum for Salvadorans and other Central Americans who came to the United States in the 1980s, recognition of asylum status as a right protected could imply an act of restitution for systematic oppression, a recognition of the state's responsibility for both violence and displacement. The granting of TPS to those legally framed as unauthorized nonimmigrants on the basis of the inhumanity of sending them back to naturalized conditions of disaster, on the other hand, reinforces the idea that the United States is a benevolent entity, caring and generous even with those who violated the country's territorial sovereignty. This interpretation of the program is extant among many who enroll in it, as well as legal practitioners, such as the lawyer who stated the following:

My personal opinion, those fortunate enough to have TPS should consider themselves lucky they have had it now for so many years. Many others just wish they could have any kind of permiso. I think their complaints are unfounded. Instead they should be grateful the government has allowed them this political tool in order to continue having permisos. (Immigration lawyer in central Arkansas, personal communication, July 2, 2007)

The circulation of a discourse of gift and gratitude on the ground ensures that these notions have life beyond the formal rationale of the statute. In addition to the frame of gift and gratitude, the language around TPS frames the program as a response to disastrous conditions in El Salvador. By rhetorically reinforcing the notion of El Salvador as a backward place of perpetual disaster, insecurity, and danger, this US policy forms part of a broader set of historical and contemporary discourses that constitute the receiving nation-state's exceptionalism as a civilized safe haven. At the same time, in contrast to refugee and asylee status, TPS-holding migrants are given no opportunity to become fully enfranchised citizens in this safe haven. In short, the phenomenon of 
Temporary Protected Status allows the US government the best of both worlds: rhetorically reproducing the notion of the United States as a site of safety and opportunity, benevolently giving refuge to unfortunates from a purportedly unlivable third world, while also allowing for the continued labor exploitation and social marginalization of migrants.

\section{Life with an Expiration Date: Living and Critiquing the Temporary Life}

Salvadorans living this condition of liminal legality under TPS in Arkansas spoke of the program from multiple angles, acknowledging the multifaceted and ambiguous way the status affects their social and working lives. Many Salvadorans appreciate the TPS program and to an extent perceive what it provides as, indeed, a type of benefit. Most with TPS status feel great relief that they do not have to fear being discovered by immigration officials to the same degree they would as unauthorized migrants, or even moral pride that their work permit makes them legitimate as local residents. Those with professional training (such as in journalism) may be able to work jobs in their profession as long as employers can accept the instability of the status, while undocumented persons with similar training work under the table in construction, work as wait-staff, start informal businesses, or use false papers and make themselves invisible in the disassembly lines of chicken processing plants. However, those who live with liminal legality also do not hesitate to criticize the indignities and inadequacies of the program. When I told one Salvadoran man I was writing a paper on TPS, he joked: "Tell them they make us renew too often. And they make us give our fingerprints every year! Do they think we are smuggling in new fingers?" ("Gerardo," personal communication, February 2007). Others express the same resentment at the invasive nature of TPS eligibility requirements and biometrics.

Some Salvadorans who are eligible for TPS do not choose to enroll for various reasons. This can be because they are not aware of their eligibility, because they are suspicious of state bureaucracies and hesitant to make themselves visible through the application process, or because they choose clandestinity over the liminal legality (and permanent surveillance) of TPS. This is a testament to the problematic nature of TPS as perceived by Salvadoran migrant interviewees. While migrants who are undocumented avoid all contact with ICE officials, those with TPS must be in contact with them on a yearly basis to renew their permits, even reporting for biometrics or personally identifying body measurements. This includes fingerprinting, which makes many Salvadorans exceedingly nervous. Gerardo, who bridled at the idea that he would have to submit to fingerprinting every year, noted accurately that such a practice is a means of state control: "They do this so they know who and where we are." Indeed, it is delineated in the TPS statutes that such information could be used when TPS is withdrawn to round up and deport those who had work permits under the program: "DHS [the Department of Homeland Security] has made clear that information it collects when an alien registers for TPS may be used to institute exclusion or deportation proceedings upon the denial, withdrawal, or expiration of TPS" (Wasem and Ester 2011, 2-3). The necropolitics of the Department of Homeland Security's militarized border enforcement (Márquez 2010) are complemented by the biopolitics of US 


\section{LAW \& SOCIAL INQUIRY}

Citizenship and Immigration Services (US-CIS) registration processes, which entail the extensive and frequent taking of biometric records. ${ }^{11}$

Some migrants comment that TPS does not go far enough as a benefit, and the United States owes Salvadorans special treatment given the long and close political entanglement between El Salvador and the United States. For a few, this means the compliance and collaboration of the Salvadoran government with US foreign policy goals, such as signing the Central American Free Trade Agreement or the provision of soldiers to the 2003 war in Iraq:

I think that they should give us certain consideration because El Salvador is the only country in all of Latin America that supports the US war in Iraq. We sent troops, and it makes me proud to see that. And we have always supported the US. But I think the politicians should see that we did something for them, now they should do something for us. ("Yessica," personal communication, November 2006)

Other interviewees emphasize that the United States had some responsibility to Salvadorans due to the US role in fomenting the Salvadoran civil war:

I don't understand why the government doesn't extend something special to Salvadorans, because El Salvador suffered a war that was practically agitated by the United States. So they owe us something for that, and more than a temporary permission. ("Camilo," personal communication, March 9, 2008)

These migrants critique the framing of TPS as "gift," arguing that the awarding of TPS is a poor restitution to Salvadorans for the US role in the decades of war and economic disaster in their country or for the ways in which the Salvadoran state has for the past thirty years complied closely with US foreign policy goals. Through their own narratives, migrants on the ground contest the cultural logic of the TPS as an unqualified act of humanitarian largesse.

A few Salvadorans emphasize the state's obligation to migrants, specifically citing historical relations between El Salvador and the United States, but it is far more common for migrants to emphasize their own moral worth as a reason for US-CIS to grant them residency. They express frustration at the difficulty of constantly renewing permits, while others who they frame as less deserving possess better options or opportunities. One man who attempted to renew had his application misfiled by a notary and lost his job at Petit Jean Poultry in Danville. He used the occasion to reflect on the absurdity of the entire system, arguing that the standards failed to reward those who merit it:

11. While this acknowledgment—even foregrounding — of the punitive aspects of the program may appear to contradict the discursive framing of TPS as a benevolent and humanitarian migrant program offering relief, these two discourses are deployed within both the statutes themselves and congressional research and commentary, without any apparent distress regarding the two-fold implications. In this way, the coupling of punitive deportation and national security discourse with celebratory discourse regarding the exceptionalism of the United States as a haven and magnet for migration here form a strong parallel with the contradictions and tensions in broader discourses about immigration in the United States. 
The government doesn't make any sense. I see people that are drunks, drug addicts, make all kinds of trouble, and they get residency easily. While others who only work, behave themselves, they are good people, and they don't give them anything. It's hard for them even to get a temporary residency. ("Ricardo" September 23, 2007)

Similarly, the grandchildren of another Salvadoran migrant, doña Magdalena, were irate when they realized how long their grandmother had been in the United States without being recognized with legal residency. Upon encountering some letters that Magda had from their mother, sent from El Salvador when she was a child, they expressed their frustration. They could not understand why "criminals" could be citizens, but not their grandmother, who had spent "so many years working hard, paying taxes, and doing everything possible to get ahead." The boy, Carlitos, promised to write a long letter to the US-CIS explaining everything about his grandmother's suffering during the war as well as sacrifices and hard work in the United States. These children, along with Ricardo and a number of other informants, espouse a meritocratic view of citizenship and social belonging. Discursively constructing Salvadoran migrants as superior within a moral hierarchy of value, they argue that those who fulfill values of work and contribution should be rewarded and enfranchised, not "criminals" or "drunks," and in the process reproduce discourses of criminality as delimiting the moral boundaries of citizenship (cf. Cacho 2012).

In addition to contesting the rationale and the hidden political meanings of TPS, Salvadoran migrants argue that TPS is more a condition of exclusion and insecurity, a tenuous form of legality that could be taken away at any moment, rather than a benefit granting security. One woman I spoke with had been working with a TPS card from 2001-2006, but her most recent petition for renewal was denied. She does not understand why:

They tell me that they don't have enough proof that I am really from El Salvador. I don't understand-I sent them my birth certificate. They were satisfied before. It seems like things are going backwards for us. ("Yessica," personal communication, November 2006)

In this context, it is understandable that some may choose to continue to work in a clandestine fashion rather than announcing their presence to the Department of Homeland Security. Many informants expressed a feeling of exasperation with both the convoluted processes of immigration law and the proliferation of false document markets:

The law punishes honest people and benefits liars. The father of my children says I should get papeles chuecos [false papers], that there are buenos chuecos [good fakes]. I am not going to put my fingerprints on a false document. I think it's all craziness. They are selling Salvadoran birth certificates to Mexicans now, with their names on them. Before, Salvadorans used to try to pass for Mexican so they could be deported to Mexico instead of El Salvador, but now the Mexicans pass themselves off as Salvadorans in order to get a work permit. I say it's a total mess. ("Soledad," personal communication, March 25, 2007) 


\section{LAW \& SOCIAL INQUIRY}

In light of Yessica's testimony above, it may be that the standards for documentation under TPS are becoming more stringent as new markets develop around falsification of documents, including markets for Salvadoran birth certificates. The state creates the demand for papeles chuecos, then casts a wide net for identity theft offenders-a net that catches some whose papers are valid, not chuecos, and nets consumers of false documents as well as those entrepreneurs who traffic in identities.

\section{CONCLUSION: TPS, STATE IDEOLOGY, AND LEGAL AMBIGUITY UNDER NEOLIBERAL REGIMES}

While TPS has been seen as a benefit for migrant workers by many legal practitioners and activists — and migrants themselves acknowledge the partial advantages - in this analysis I have emphasized the ways that TPS both produces and mediates conflicts between economic forces, political discourses, and dynamics of social exclusion and inclusion, all while failing to provide migrants with a path toward citizenship or meaningful social and territorial belonging. As with other temporary work status programs before it (Le Espiritu 2000; Mize and Swords 2010), TPS performs practical work for the state and corporations, providing them with a relatively docile and legally immobilized population. Simultaneously, these legal forms help construct the nationstate as orderly and sovereign in a moment of alarmism regarding the integrity and security of nations and their relations to territory and population. The condition of liminal legality impels a greater degree of clandestine behavior and social isolation for migrants (Bailey et al. 2002; De Genova 2005), thus contributing to the social divisions that underpin cultural narratives and images portraying immigrants as an external threat to the nation.

To add historical insult to legal injury, the program is set up to deny and deflect state responsibility for the displacement of Salvadorans and the legitimate claims many have to asylum. The discursive structure of the legal program and its deployment following the earthquakes reinforces US exceptionalism, performing a kind of humanitarian grift that contributes to Salvadorans' subordination and marginalization. By narrating the United States as source of refuge for those displaced by natural disaster, TPS contributes to a notion of the United States as, in Nicholas de Genova's words, the "self-anointed refuge of liberty and opportunity" (2002, 421) —and a notion of El Salvador as a perpetually disaster-ridden land.

Finally, the invasive and unwieldy practice of frequent renewal and biometric measurements doubly subjects TPS recipients to state authority. The practices of state and corporate surveillance required by temporary permit programs may make things worse for migrants. TPS recipients have their years of residency, time that would otherwise be providing tools for them eventually to combat an order of deportation, legally effaced.

Temporary Protected Status is multifaceted and ambiguous, both in semiotic and pragmatic terms. While on the one hand TPS represents a political victory for Salvadoran transnational migrants and their allies and while migrants can strategically deploy their status "as if" they were legal, as a state response to the demands of the migrant community it also serves the purposes of the nation-state: it circumscribes and 
reinscribes the racialized boundaries of national belonging by subordinating the beneficiaries to indefinite liminal legality. It legitimizes the state's actions as it constructs stratified systems of low-wage labor and social exclusion and provides few structural benefits to migrants along with its fees, biometric requirements, and bureaucratic delays.

Simultaneously symbolically reinforcing the idea of the United States as a benevolent force in the world and placating the nativist lobby by keeping migrants unenfranchised and supposedly temporary, the TPS is a flexible technology subjecting migrants through temporariness and in the process contingently resolving several political problems. Although TPS permits many Salvadorans to avoid deportation, it also imposes tremendous constraints on their mobility and transnational practices: Salvadorans are constrained from returning to their country to visit because they fear return trips will be seen as evidence that migration is a personal choice rather than a necessity due to the situation of instability in El Salvador, yet they are also prevented from settling by the always-imminent termination of their work permits. As others have noted, "Salvadorans in temporary status programs have been immobilized in a limbo of spatial, temporal, economic, social, political and psychological dimensions" (Miyares et al. 2003, 79). This singular legal condition must be understood in its full ramifications, social as well as statutory:

Although permanent temporariness springs from the fact that many immigrants now live and work under TPS, it is more than a static thing imposed upon individuals and groups by legal means. Indeed, as permanent temporariness is actively resisted, and as it creeps into all the nooks and crannies of Salvadoran daily life, we regard it as a way of being, a kind of space of action. We thus interpret permanent temporariness as exerting disciplining power over bodies, families, and social fields. (Bailey et al. 2002, 139)

I would suggest that this "permanent temporariness," though quite specific to Salvadorans' legal situation, involves dynamics of discipline and exclusion that have also been faced by migrants more broadly. In other words, the ambiguous and occluded subjection and disciplining entailed by liminal legality is not limited to TPS or HB visa status, but represents a broader and ongoing technology of citizenship law that is made visible in this particular instance.

Through an understanding of Salvadorans' TPS status as a structural form of differential exclusion, we can see its continuity with other partial forms of migrant incorporation, even beyond other guest-worker provisions such as the $\mathrm{H} 2$ visas and the bracero programs. Rather than seeing TPS as a way of being and legal frame that is radically different from other ways of managing and disciplining migrants, I would propose that the formality of liminal legality can reveal similar dynamics of constraint and exclusion that remain implicit in other situations. Ethnographic work on the experience of temporariness (and on migrants' discourses of resistance to state attempts at appropriation and disciplining) can reveal the dynamics of agency in diverse forms and conditions of ambiguous legal status, graduated forms of citizenship, social constructions of some persons as "out of place." Such research can also illuminate the ways these stratifications lead to limited access to rights in everyday life.

Temporary workers remain politically disenfranchised and often socially marginalized and their sense of ownership and stability is contingent and fragile. By bringing 


\section{LAW \& SOCIAL INQUIRY}

the qualities of undocumented experience into the open and documenting them as legitimate and state ratified, temporary work permit programs such as TPS make explicit the relations of power and labor management that remain implicit in the clandestine practices around fully unauthorized status and deportability, as well as the racialized social and legal processes constraining full access to civil rights for legal permanent residents and citizens of color.

While the creation and expansion of temporary worker programs may briefly reconcile the symbolic, social, political, and economic contradictions that the nationstate negotiates in an era of neoliberal globalization, it will not resolve the problematic conditions of life for migrants and may, in fact, create a semipermanent underclass of disciplined temporary persons, their personhood constrained by a permanent liminal legality. This type of immigration policy is a way for neoliberalism and the ideology of the nation-state system to work hand in hand and for the historical and economic entanglement of sending and receiving countries to be occluded. Although migrants may express resistance to the indignities, surveillance, and insecurity of TPS through their expressions of agency, they nonetheless live a structural, symbolic, and social condition in which they are legally recognized as workers, but effaced as full persons.

\section{REFERENCES}

Agamben, Giorgio. 2005. State of Exception. Chicago, IL: University of Chicago Press.

Bailey, Adrian J., et al. 2002. (Re)Producing Salvadoran Transnational Geographies. Annals of the Association of American Geographers 92 (1): 125-44.

Bruno, Andorra. 2012. Immigration of Temporary Lower-Skilled Workers: Current Policy and Issues. Washington, DC: Congressional Research Service.

Cacho, Lisa Marie. 2012. Social Death: Racialized Rightlessness and the Criminalization of the Unprotected. New York: New York University Press.

Calavita, Kitty. 1998. Immigration, Law, and Marginalization in a Global Economy: Notes from Spain. Law and Society Review 32 (3): 529-66.

2005. Immigrants at the Margins: Law, Race, and Exclusion in Southern Europe. Cambridge: Cambridge University Press.

Capps, Randolph, Everett Henderson, John D. Kasarda, James H. Johnson, Jr., Stephen J. Appold, Derrek L. Croney, Donald J. Hernandez, and Michael E. Fix. 2007. A Profile of Immigrants in Arkansas. Washington, DC: Urban Institute.

Capps, Randolph, Kristen McCabe, Michael Fix, and Ying Huang. 2013. A Profile of Immigrants in Arkansas: Changing Workforce and Family Demographics, Volume 1. Little Rock, AR: Winthrop Rockefeller Foundation and Migration Policy Institute.

Coutin, Susan Bibler. 1998. From Refugees to Immigrants: The Legalization Strategies of Salvadoran Immigrants and Activists. International Migration Review 32 (4): 901-25.

—. 2000. Legalizing Moves: Salvadoran Immigrants' Struggle for US Residency. Ann Arbor, MI: University of Michigan Press.

- 2007. Nations of Emigrants: Shifting Boundaries of Citizenship in El Salvador and the United States. Ithaca, NY: Cornell University Press.

2011. Falling Outside: Excavating the History of Central American Asylum Seekers. Law $\mathcal{E}$ Social Inquiry 36 (3): 569-96.

Coutin, Susan, and Barbara Yngvesson. 2008. Technologies of Knowledge Production: Law, Ethnography, and the Limits of Explanation. PoLAR: Political and Legal Anthropology Review 31 (1): 1-7.

De Genova, Nicholas P. 2002. Migrant "Illegality" and Deportability in Everyday Life. Annual Review of Anthropology 31:419-47. 
- 2005. Working the Boundaries: Race, Space, and "Illegality" in Mexican Chicago. Durham, NC: Duke University Press.

Dery, David. 1998. "Papereality" and Learning in Bureaucratic Organizations. Administration and Society 29 (6): 677-89.

González, Juan. 2000. Harvest of Empire: A History of Latinos in America. New York: Viking.

Hamilton, Nora, and Norma Stoltz Chinchilla. 2001. Seeking Community in a Global City: Guatemalans and Salvadorans in Los Angeles. Philadelphia, PA: Temple University Press.

Haney López, Ian. 1996. White by Law: The Legal Construction of Race. New York: New York University Press.

Kapoor, Ilan. 2008. The Postcolonial Politics of Development. New York: Routledge.

Kretsedemas, Phillip. 2009. Immigration Enforcement and the Complication of National Sovereignty: Understanding Local Enforcement as an Exercise in Neoliberal Governance. In Nation and Migration Past and Future, ed. David G. Gutierrez and Pierrette Hondagneu-Sotelo, 51-71. Baltimore, MD: Johns Hopkins University Press.

Lakhani, Sarah. 2014. From Problems of Living to Problems of Law: The Legal Translation and Documentation of Immigrant Abuse. Law $\mathcal{E}$ Social Inquiry 39 (3):

Le Espiritu, Yen. 2000. Asian American Men and Women. Walnut Creek, CA: Altamira Press.

Mahler, Sarah. 1995. Salvadorans in Suburbia: Symbiosis and Conflict. Boston, MA: Allyn \& Bacon.

Márquez, John. 2010. Nations Re-Bound: Race and Necropolitics at the US and EU Borders. Paper presented at the Annual Law and Society Association Annual Meeting, XX, in Chicago, IL.

Marrow, Helen. 2011. New Destination Dreaming: Immigration, Race, and Legal Status in the American South. Stanford, CA: Stanford University Press.

Massey, Douglas S. 2008a. Categorically Unequal: The American Stratification System. New York: Russell Sage Foundation.

—, ed. 2008b. New Faces in New Places: The Changing Geography of American Immigration. New York: Russell Sage Foundation.

Massey, Douglas S., and Katherine Bartley. 2005. The Changing Legal Status Distribution of Immigrants: A Caution. International Migration Review 39 (2): 469-84.

Massey, Douglas S., Jorge Durand, and Nolan J. Malone. 2002. Beyond Smoke and Mirrors: Mexican Immigration in an Era of Economic Integration. New York: Russell Sage Foundation.

Menjívar, Cecilia. 2006. Liminal Legality: Salvadoran and Guatemalan Immigrants' Lives in the United States. American Journal of Sociology 111 (4): 999-1037.

Menjívar, Cecilia, and Leisy Ábrego. 2012. Legal Violence: Immigration Law and the Lives of Central American Immigrants. American Journal of Sociology 117 (5): 1380-1421.

Miyares, Ines M., Richard Wright, Alison Mountz, Adrian J. Bailey, and Jennifer Jonak. 2003. The Interrupted Circle: Truncated Transnationalism and the Salvadoran Experience. Journal of Latin American Geography 2 (1): 74-86.

Mize, Ronald L., and Alicia Swords. 2010. Consuming Mexican Labor: From the Bracero Program to NAFTA. Toronto, ON: University of Toronto Press.

Motomura, Hiroshi. 2008. Immigration Outside the Law. Columbia Law Review 108 (8): 2037-97.

Mountz, A., R. Wright, I. Miyares, and A. J. Bailey. 2002. Lives in Limbo: Temporary Protected Status and Immigrant Identities. Global Networks 2:335-56.

Ngai, Mae M. 2005. Impossible Subjects: Illegal Aliens and the Making of Modern America. Princeton, NJ: Princeton University Press.

Ong, Aihwa. 1999. Flexible Citizenship. Durham, NC: Duke University Press.

. 2006. Neoliberalism as Exception. Durham, NC: Duke University Press.

Paret, Marcel. Forthcoming. Legality and Exploitation: Immigration Enforcement and the US Migrant Labor System. Latino Studies 12 (4).

Sadowski-Smith, Claudia. 2009. Unskilled Labor Migration and the Illegality Spiral: Chinese, European, and Mexican Indocumentados in the United States, 1882-2007. In Nation and Migration Past and Future, ed. David G. Gutierrez and Pierrette Hondagneu-Sotelo, 277-302. Baltimore, MD: Johns Hopkins University Press.

Striffler, Steve. 2005. Chicken: The Dangerous Transformation of America's Favorite Food. New Haven, CT: Yale University Press. 


\section{LAW \& SOCIAL INQUIRY}

Wasem, Ruth Ellen, and Karma Ester. 2011. Temporary Protected Status: Current Immigration Policy and Issues: CRS Report for Congress. Washington, DC: Congressional Research Service.

\section{STATUTES CITED}

Nicaraguan Adjustment and Central American Relief Act, 8 U.S.C. §§ 201-203 (1997).

Temporary Protection Status, 8 U.S.C. § 1254a (1990). 


\section{AUTHOR QUERY FORM}

Dear Author,

During the preparation of your manuscript for publication, the questions listed below have arisen. Please attend to these matters and return this form with your proof.

Many thanks for your assistance.

\begin{tabular}{|l|l|l|}
\hline Query References & Query & Remarks \\
\hline 1 & $\begin{array}{l}\text { AUTHOR: In regard to Bailey et al. 2002, it is } \\
\text { conventional to give the names of at least the } \\
\text { first six authors. }\end{array}$ & \\
\hline 3 & $\begin{array}{l}\text { Is this the correct way to indicate this? Or will } \\
\text { you replace it with a different indicator? }\end{array}$ & \\
\hline 4 & $\begin{array}{l}\text { AUTHOR: Please provide month and date of } \\
\text { the meeting for Marquez 2010. }\end{array}$ & \\
\hline 5 & $\begin{array}{l}\text { AUTHOR: There is no Ngai 2004 listed in } \\
\text { References. }\end{array}$ & \\
\hline
\end{tabular}

